\title{
UPPER-MANTLE XENOLITHS IN THE HOMESTEAD KIMBERLITE, CENTRAL MONTANA, USA: DEPLETED AND RE-ENRICHED WYOMING CRATON SAMPLES
}

\author{
B. Carter Hearn, Jr. \\ U.S. Geological Survey, USA
}

\begin{abstract}
The Homestead kimberlite was discovered by consulting geologist Peter Ellsworth in 1999, in the Grassrange area of aillikite, alnoite, monchiquite and carbonatite dikes, diatremes, and a few sills in central Montana (Ellsworth, 2000). The concealed basement is part of the Archean Wyoming craton. The kimberlite underlies two low hills, and may be either a single pipe 450 by $150 \mathrm{~m}$ (Ellsworth, 2000 ), with a zone of included shale between the two hills, or may be a double pipe, if the zone of shale is wall rock rather than a brecciated screen. Wall rock is the Skull Creek Shale Member of the Thermopolis Formation, consisting of black shale and thin beds of rusty-weathering siltstone and sandstone. The eastern pipe, 130 by $90 \mathrm{~m}$, underlies the eastern hill and the saddle, and contains orange altered kimberlite breccia with xenoliths of baked sedimentary rocks and carbonate-silica altered peridotites. In the saddle area, gray kimberlite breccia and locally massive dark gray fresh kimberlite contain partially serpentinized peridotite xenoliths. The Homestead kimberlite has not been dated, but its age is probably middle Eocene, similar to phlogopite ages from nearby intrusions: Elk Creek Butte, 2 km east-southeast, $50.34 \mathrm{Ma}$; Yellow Water Butte, 51.41 Ma (Mitchell and Bergman, 1991); Winnett sill, 50.2 Ma (Marvin et al, 1980).
\end{abstract}

The western pipe, 300 by $150 \mathrm{~m}$, underlying the western hill, contains gray to orange breccias of kimberlite fragments and abundant sedimentary rock fragments, tuffisitic kimberlite breccia (in part containing pelletal autoliths), soft gray, green, brown, or orange altered kimberlite, and massive dark gray fresh kimberlite. Some breccia fragments are silicified. Peridotite xenoliths are abundant on the east and west sides of the western hill. On the northeast, a 3 by $3 \mathrm{~m}$ area of light gray baked siliceous shale is probably from the Mowry Shale (Upper Cretaceous), and has descended about $150 \mathrm{~m}$. This is the only large subsided or down-faulted xenolith recognized so far in the pipe. A nearby orange altered carbonate-rich dike (carbonatite?) trends $\mathrm{S} 60^{\circ} \mathrm{W}$, away from the pipe.

The nickel geothermometer shows that $\mathrm{Cr}$ pyrope xenocrysts are in the diamond window; one microdiamond was recovered by caustic fusion of a $45 \mathrm{~kg}$ sample of kimberlite (Ellsworth, 2000).

\section{Kimberlite}

The kimberlite contains 25 to 30 modal percent olivine, from 0.1 to $5 \mathrm{~mm}$ in size. Many of the larger olivines $(0.5$ to $5 \mathrm{~mm}$ ) have rounded shapes and are xenocrystic. Smaller olivines, less than $0.5 \mathrm{~mm}$, have irregular to euhedral shapes, and their borders tend to contain FeTi oxide grains. Some smaller olivines may have xenocrystic cores with magmatic rims developed in the kimberlite. The matrix contains phlogopite, monticellite, sparse diopside, serpentine, chlorite, calcite, perovskite, spinel, pectolite, and hydrous $\mathrm{Ca}$ and $\mathrm{Ca}-\mathrm{Al}$ silicates with $\mathrm{Na}$.

Olivines have a wide range of Fo contents, from 82 to 96.5. Some systematic variations are related to core-rim zoning and size. Most large and medium-size olivines ( 0.25 to $5 \mathrm{~mm}$ ) have cores of Fo 90.5 to 96.5 , NiO 0.36 to $0.48 \mathrm{wt} \%$, with rims of Fo 87 to 90.5 and $\mathrm{NiO} 0.07$ to 0.15 wt $\%$. Fo values greater than 93 are unusual for peridotitic olivines, but some Homestead xenoliths contain olivines with Fo values as high as 93.8. High Fo cores may be xenocrysts from disaggregated peridotite xenoliths, or could be in part magmatic (as shown by olivines up to Fo 94.2 in the Zortman and Ricker Butte alnoites). Small and very small olivines $(<0.25 \mathrm{~mm})$ tend to cluster in an intermediate range of Fo 90.3 to 90.8 , with intermediate $\mathrm{NiO}$ contents of 0.20 to $0.35 \mathrm{wt} \%$. It appears that $0.25-5 \mathrm{~mm}$ xenocrystic olivines developed more iron-rich rims, and subsequently, olivines of $<0.25 \mathrm{~mm}$ size crystallized in a higher $\mathrm{Mg}$ environment, resulting in intermediate Fo contents. Olivines tend to show an antithetic relationship of $\mathrm{Ni}$ and $\mathrm{Ca}$, as expected for xenocrystic vs. magmatic olivine grains or zones. As Fo content decreases, Ni decreases and $\mathrm{Ca}$ increases. However, variation of $\mathrm{CaO}$ content of olivines is inconsistent. Although many large and medium size olivines tend to show low $\mathrm{CaO}$ in cores $(0.02-0.20 \mathrm{wt} \%)$, and higher $\mathrm{CaO}$ in rims (0.40-1.05), some have about 1 $\mathrm{wt} \% \mathrm{CaO}$ in cores and $0.2-0.3$ in rims. For the small olivines $<0.25 \mathrm{~mm}$, about $2 / 3$ have high $\mathrm{CaO}$ content, 0.9$1.1 \mathrm{wt} \%$, and $1 / 3$ have low $\mathrm{CaO}$ content, 0.10-0.35.

The larger oxide grains $(0.04$ to $0.1 \mathrm{~mm})$ in the groundmass have cores of $\mathrm{CrFeAlMg}$ spinel and rims of MgTi magnetite. Some spinels have poorly developed atoll texture. Variation of $\mathrm{Cr} \#, \mathrm{Mg} \#$, and Ti content (Fig. 1) shows core-rim trends similar to the kimberlite Trend 2 (Mitchell, 1986). $\mathrm{MnO}$ contents are low, 0.2-0.5, and $\mathrm{Nb} 2 \mathrm{O} 5$ contents are very low, $0.00-0.12 \mathrm{wt} \%$.

Anhedral to irregular $0.01-0.1 \mathrm{~mm}$ monticellite grains occur as multi-crystalline areas on borders of some forsteritic olivines, and are scattered throughout the matrix. The $\mathrm{X}_{\mathrm{Ca}}$ contents $(100 \mathrm{Ca} /(\mathrm{Ca}+\mathrm{Mg}))$ of monticellite, 47.949.8 , imply temperatures of 800 to $900^{\circ} \mathrm{C}$, if in equilibrium with small olivines, based on the experimental data of Davidson and Mukhopadhyay (1984). 


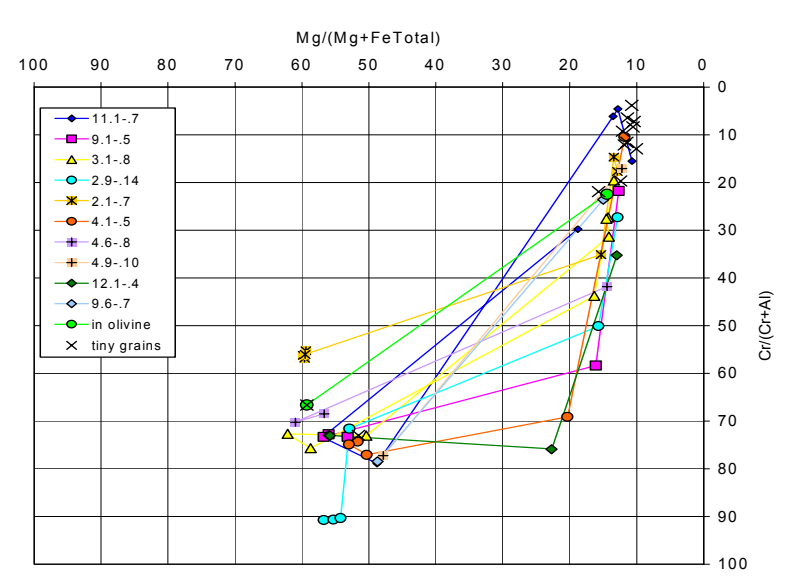

Figure 1: Zoning of groundmass spinels.

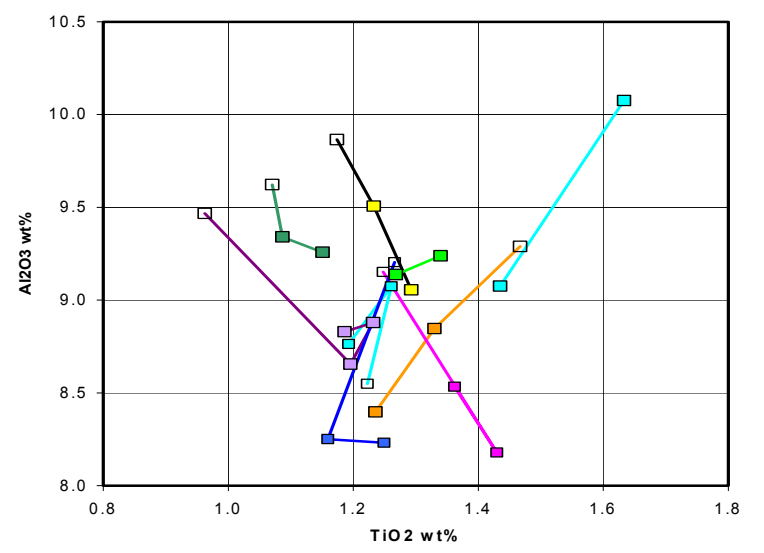

Figure 2: TiO2-A12O3 zoning of groundmass phlogopites; open symbols $=$ rims, closed symbols $=$ cores .

Phlogopites have low Al2O3 (8.1-10.1 wt \%) and $\mathrm{TiO} 2$ (0.9-1.6 wt $\%)$ contents. Limited core-rim zoning in most grains is kimberlitic with slight decrease in $\mathrm{TiO} 2$ with increasing $\mathrm{Al} 2 \mathrm{O} 3$; a few show opposite trends of decreasing $\mathrm{A} 12 \mathrm{O} 3$ from cores to rims (Fig. 2). $\mathrm{BaO}$ increases from cores $(0.39-0.93)$ to rims $(0.65-1.15)$. $F$ ranges from 1.13 to 1.52 with no core-rim variation; $\mathrm{Cl}$ is below detection. $\mathrm{FeO}$ and $\mathrm{Mg} \#$ show no consistent core-rim trend.

\section{Xenoliths}

Xenoliths from below are Paleozoic limestone and dolomite, sparse crustal granulites, amphibolites, and metagabbros, and upper-mantle peridotites and pyroxenites. Locally, peridotite xenoliths are remarkably abundant and large, up to $0.7 \mathrm{~m}$, in closely packed arrays that resemble a boulder conglomerate. These may be the largest known garnet peridotites known in the U.S., and possibly the largest known in North America. No eclogites are present. Megacrysts (size $>1 \mathrm{~cm}$ ) of garnet (gar), clinopyroxene (cpx), orthopyroxenes (opx), and ilmenite, common in many kimberlites, are absent.

The xenoliths show slight to extensive serpentinization. Composite xenoliths show relationships among peridotite, pyroxenite, and phlogopite-bearing veins. The xenolith suite is dominated by dunites and harzburgites, containing garnet (gar), garnet and spinel (sp), or sp only. Three of 26 studied peridotite xenoliths are low-Ca gar-sp harzburgites containing G-10 garnets with $1.97,3.92,3.47 \mathrm{wt} \% \mathrm{CaO}$, and 3.87, 5.05, $4.75 \mathrm{wt} \% \mathrm{Cr} 2 \mathrm{O} 3$ respectively; two of these contain sparse cpx.

Pyroxenites, found mainly as veins or selvedges in peridotite xenoliths, are sp websterite, gar-sp websterite, gar websterite, and gar orthopyroxenite; some of these contain phlogopite. Many peridotites contain phlogopite as disseminated grains, as rims around garnets, in cpx-sp clots, or as crosscutting veins with or without cpx or opx. Phlogopite-rich zones may form one or more borders of some peridotite xenoliths, indicating that the peridotite probably has split along phlogopite veins. Textures are mainly coarse granular, only $5 \%$ are porphyroclastic, in contrast to Williams kimberlite xenoliths, of which about $50 \%$ are porphyroclastic.

The xenolith suite indicates ancient major-element depletion as in other Wyoming craton assemblages. Younger enrichment events are shown by tectonized or undeformed veins of orthopyroxenite, clinopyroxenite, and websterite with gar and/or sp. Cr-diopside-rich bands probably represent tectonized earlier clinopyroxenite veins. Later undeformed Cr-diopside clinopyroxenite veins cut across some peridotites. Phlogopite-bearing veins may represent earlier K-metasomatism and/or late kimberliterelated addition. Proportions of xenolith lithologies may be highly variable in different parts of the kimberlite. Among the collected xenoliths (a biased selection, in part based on the presence of unusual textures, macroscopic gar, cpx, veins, or composite nature), $8 \%$ are lherzolite (3\% gar, $3 \%$ gar - sp, $2 \%$ sp), $61 \%$ are harzburgite ( $22 \%$ gar, $25 \%$ gar sp, $14 \% \mathrm{sp}$ ), and $31 \%$ are dunite ( $2 \%$ gar, $5 \%$ gar - sp, $24 \%$ sp), (using $<5$ percent cpx content to define harzburgites, and $<5$ percent of either pyroxene to define dunites). A more representative estimate for xenoliths $>5 \mathrm{~cm}$ size in one small area, 1.5 by $3 \mathrm{~m}$, of exposed kimberlite in the saddle is: $21.5 \%$ harzburgite $(20.3 \% \mathrm{sp}, 1.2 \%$ gar), $77.9 \%$ dunite (76.7 sp, $0.6 \%$ gar), $0 \%$ lherzolite, and $0.6 \%$ amphibolite; about $4 \%$ contain macroscopic phlogopite. Both xenolith counts indicate that the suite is dominantly depleted, as in other xenolith suites from the Wyoming Craton (Williams kimberlite, Macdougal Springs diatreme, Froze-to-Death Butte, Ingomar South dike, Highwood and Bearpaw Mountains).

Garnet-bearing peridotites have a range of 1180-1390 ${ }^{\circ} \mathrm{C}$ and 38-47 kb, (Brey and Kohler (1990) methods), in the graphite stability field close to the diamond boundary (Fig. 3). Low-Ca harzburgites fall in about the same T range, 


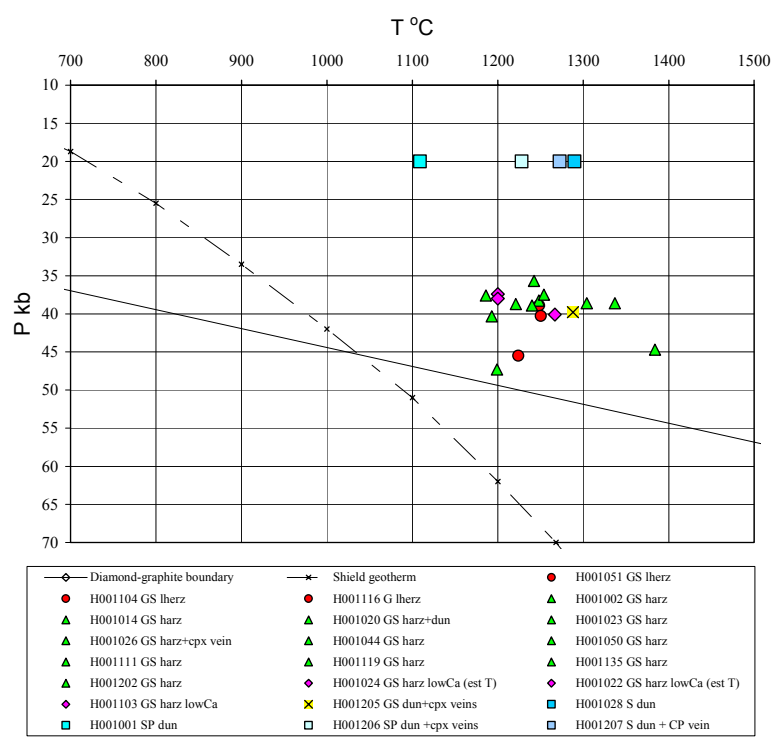

Figure 3: Calculated $\mathrm{T}$ and $\mathrm{P}$ of xenoliths by Brey and Kohler (1990) methods. Symbols: circles = gar, gar-sp lherzolites, triangles $=$ harzburgites, diamonds $=$ low-Ca harzburgites, $\mathrm{x}=$ garsp dunite, squares $=\mathrm{sp}$ dunites.

using $\mathrm{Ca}$ in sparse clinopyroxene or $\mathrm{Fe} / \mathrm{Mg}$ in olivinegarnet pairs. For most spinel peridotites, pyroxene T's for assumed $20 \mathrm{~kb}$ are in the same range, possibly indicating heating of the shallow mantle. Olivine-spinel temperatures are consistently much lower, indicative of re-equilibration, as is common in other xenolith suites, and thus are not reliable for thermometry.

\section{Xenocrysts}

Garnet color has been used to pick out Cr-rich pyrope garnets that are pertinent to evaluation of diamond prospectivity and presence of upper mantle material. $\mathrm{Cr}$ pyropes are usually described as purple, lilac, or lavender, and fewer are termed red or deep red. Size is a factor in apparent color, as smaller fragments of purple $\mathrm{Cr}$ pyrope can appear pink. Garnet xenocrysts in the Homestead kimberlite are mainly purple G-9 Cr-pyropes, with an overall range of 2.3 to $6.2 \mathrm{wt} \% \mathrm{Cr} 2 \mathrm{O} 3$ (Fig. 4). Purple garnets from the east hill are clustered in a narrower range of 3 to $4 \mathrm{wt} \% \mathrm{Cr} 2 \mathrm{O} 3$. The proportion of purple G-10, low$\mathrm{Ca}$ pyropes ranges from $2 \%$ to $12 \%$ in various pan concentrates. Subordinate pink and orange garnets with $<0.2 \mathrm{wt} \% \mathrm{Cr} 2 \mathrm{O} 3$ are mostly almandines, from crustal rocks (Fig. 5). Some pink garnets and a few orange garnets that have low $\mathrm{Cr} 2 \mathrm{O} 3$ contents of 1.4 to $3.2 \mathrm{wt} \%$ may be from pyroxenites or from low-Cr lherzolites; their $\mathrm{TiO} 2$ contents are too low for garnet megacryst fragments. Eclogitic garnets (with $\mathrm{Na} 2 \mathrm{O}$ greater than or equal to $0.07 \mathrm{wt} \%$ ) are absent. Pyrope grains that are larger or more Cr-rich

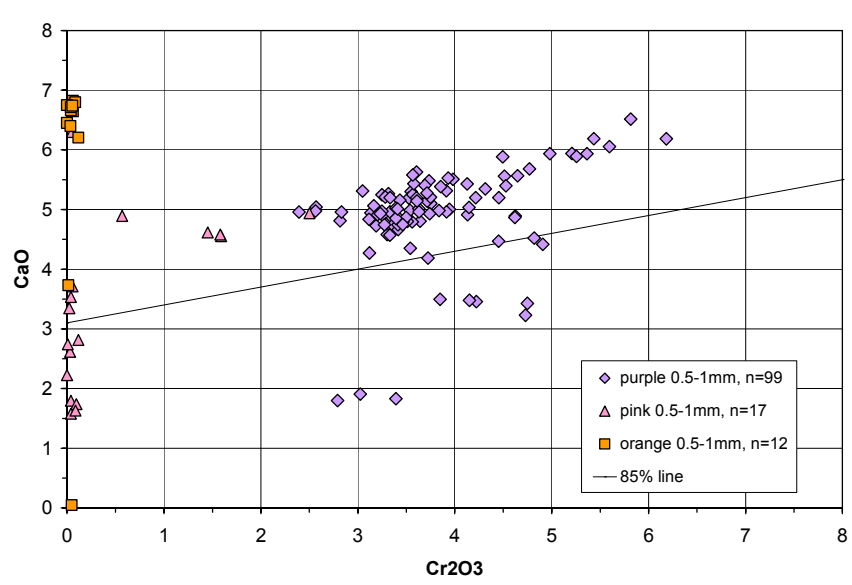

Figure 4: CaO-Cr2O3 composition of garnet xenocrysts, saddle area.

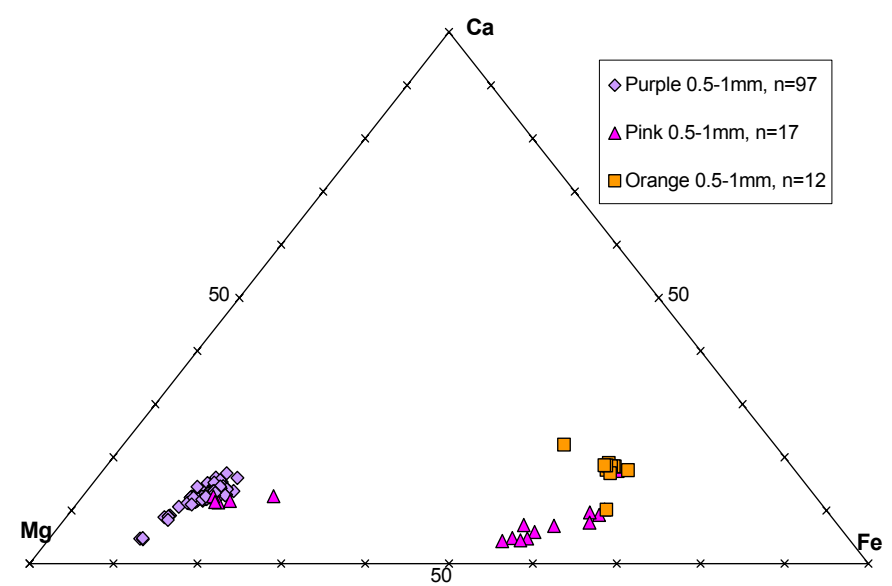

Figure 5: Ca-Mg-Fe composition of garnet xenocrysts, east slope of west hill.

show a metameric color change from purple in incandescent light, to gray, blue-gray, or bluish in daylight-type fluorescent light (Springfield and Mansker, 1985). The purple pyrope xenocrysts show a G9 lherzolitic trend that is about 0.5 to $1.5 \mathrm{wt} \% \mathrm{CaO}$ above the $85 \%$ line of Gurney (1984) and is parallel to the $85 \%$ line (Fig. 4).

Cr-spinel xenocrysts have $\mathrm{MgO}$ and $\mathrm{Cr} 2 \mathrm{O} 3$ contents (Fig. 6) that are clustered in the ranges $11-16 \mathrm{MgO}$ and 48 - $59 \mathrm{wt} \% \mathrm{Cr} 2 \mathrm{O} 3$, with a few containing $60-65 \mathrm{wt} \%$ $\mathrm{Cr} 2 \mathrm{O} 3$. About $10 \%$ are in the diamond inclusion field of Smith et al (1994). Magnetic and non-magnetic spinels (by hand magnet) show no systematic differences in $\mathrm{Cr} 2 \mathrm{O} 3$ or $\mathrm{MgO}$ content, suggesting that the magnetic character is due to thin rims of Ti magnetite on some spinels.

Mg-ilmenite xenocrysts are uncommon and most have been found in pan concentrate from the saddle area west of the East Hill. $\mathrm{MgO}$ contents are 7 to $11 \mathrm{wt} \%, \mathrm{Cr} 2 \mathrm{O} 3$ contents are $0.8-1.9 \mathrm{wt} \%$, and $\mathrm{Fe} 3 /(\mathrm{Fe}$ total) values are 0.17 to 0.31 , favorable for diamond preservation in the kimberlite. 


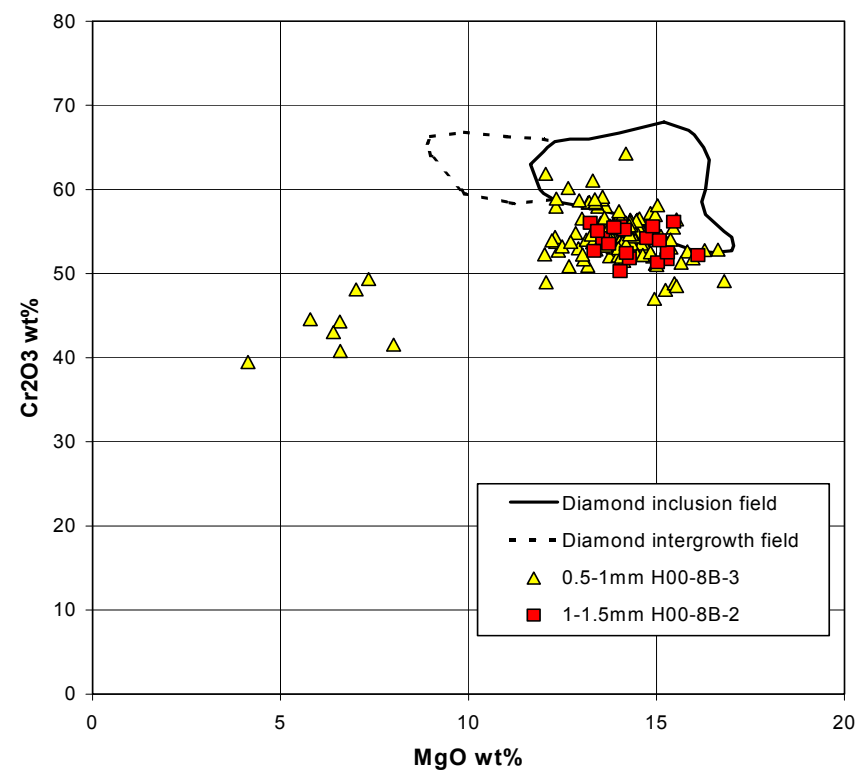

Figure 6: $\mathrm{MgO}-\mathrm{Cr} 2 \mathrm{O} 3$ compositions of 179 spinel xenocrysts, saddle area.

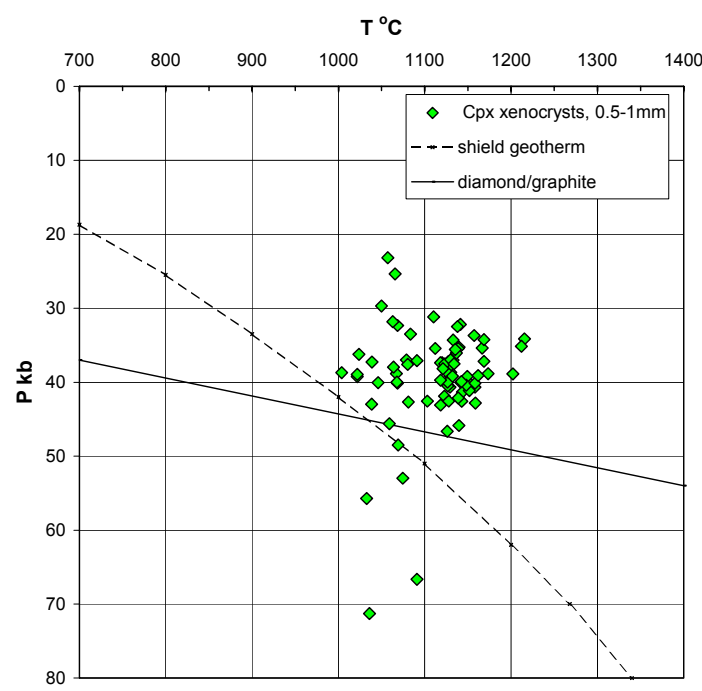

Figure 7: Calculated $\mathrm{T}$ and $\mathrm{P}$ of clinopyroxene xenocrysts (Nimis and Taylor 2000 method); east slope of west hill.

Clinopyroxene xenocrysts are $\mathrm{Cr}$ diopsides, with wide ranges in $\mathrm{Al} 2 \mathrm{O} 3, \mathrm{Cr} 2 \mathrm{O} 3$, and $\mathrm{Na} 2 \mathrm{O}(0.46-7.69,1.03-3.86$, and 1.31-3.75 respectively, for $\mathrm{Cr}$ diopsides from the east slope of the west hill). Other $\mathrm{Cr}$ diopsides contain as much as $4.2 \mathrm{wt} \% \mathrm{Cr} 2 \mathrm{O} 3$. The calculated temperatures and pressures for $\mathrm{Cr}$ diopside xenocrysts from the east slope of the west hill, by the Nimis and Taylor (2000) method, are mostly in the ranges 1000 to $1200{ }^{\circ} \mathrm{C}$, and 30 to $48 \mathrm{~kb}$, with a few in the diamond stability field (Fig. 7). Cr diopsides in other pan concentrates show similar ranges of calculated temperature and pressure.

\section{REFERENCES}

Brey, G.P., and Kohler, T., 1990. Geothermobarometry in fourphase lherzolites: New thermometers and practical assessment of existing thermobarometers. J. Petrol. 31, $1353-1378$

Davidson P.M., and Mukhopadhyay, D.K., 1984. Ca - Fe - Mg olivines: phase relations and a solution model. Contrib. Mineral. Petrol. 86, 256-263.

Ellsworth, P.C., 2000. Homestead kimberlite: new discovery in central Montana. Guidebook, $25^{\text {th }}$ Annual Field Conference, Tobacco Root Geological Society, 14-20.

Hearn Jr., B.C., and McGee, E.S, 1984. Garnet peridotites from Williams kimberlites, north-central Montana, U.S.A. In: J. Kornprobst (Ed.), Kimberlites II: The Mantle and CrustMantle Relationships. Elsevier, Amsterdam, pp. 57-70.

Hearn Jr., B.C., 1999. Peridotite xenoliths from Porcupine Dome, Montana, USA: Depleted subcontinental lithosphere samples in an olivine-phlogopite-carbonate magma. In: J. J. Gurney, J. L. Gurney, M. D. Pascoe and S. H. Richardson (Eds.), Proc. 7th Internat. Kimberlite Conf. 1, Dawson Volume. Red Roof Design, Cape Town, pp. 353360 .

Marvin, R.F., Hearn, B.C., Jr., Mehnert, H H., Naeser, C.W., Zartman, R.E. and Lindsey, D.A., 1980. Late CretaceousPaleocene-Eocene igneous activity in north-central Montana. Isochron/West 29, 5-25.

Mitchell, R.H., 1986. Kimberlites: Mineralogy, Geochemistry, and Petrology. Plenum Press, New York.

Mitchell, R.H., and Bergman, S.C., 1991. Petrology of Lamproites. Plenum Press, New York.

Nimis, P., and Taylor, W. R., 2000. Single clinopyroxene thermobarometry for garnet peridotites. Part 1. Calibration and testing of a Cr-in-Cpx barometer and an enstatite-inCpx thermometer. Contrib. Mineral. Petrol. 139, 541-554.

Smith, C.B., Lucas, H., Hall, A.E., and Ramsay, R.R., 1994. In: Meyer,H.O.A., and Leonardos, O.H. (Eds.), Diamonds: Characterization, Genesis and Exploration, CPRM, Proc. $5^{\text {th }}$ Int. Kimb. Conf., v.2, pp. 312-318.

Springfield JT and Mansker WL, 1985, Factors affecting garnet metamerism and applications in kimberlite evaluation/exploration. Geol. Soc. America Abstracts with Programs 17, 193.

Contact: BC Hearn Jr., US Geological Survey, 954 National Centre, Reston VA 20192 USA, E-mail: chearn@usgs.gov 